\title{
2 重配向した6,10-ナイロンフィラメントの圧縮変形
}

(昭 和 45 年 1 月 30 日受理)

\author{
黒川昌孝・小西孝・滝文夫・亀井良祐 ${ }^{* 1}$
}

著者らは 2 重配向 6,10-ナイロンフィラメントと分子鎖と直角の力向に圧縮したときにできる变形帯を光学および電子顕微鏡で 研究した。

試料を(010) 面に垂直に圧縮するとその横断面に約 $40^{\circ}$ の斜交バンドが認められる。一方(010)面に平行に圧縮するとキンクを 形成して結晶が回転してゆくのが認められる。

試料を(010) 面に垂直に $180^{\circ} \mathrm{C} て ゙$ 熱圧縮すると緃方向に局部的に収縮した段階状の面が現われる。この移動は压縮面で観察され る变形帯によるものと思われる。これらの局所的变形の電子影微鏡による観察結果について述べる。

\section{1 緒言}

高分子, 特に結晶性高分子の塑性変形に関係し多くの報告 ${ }^{1)}$ が 出されている。変形带の形成はこのよらな塑性変形の一つの特徴 である。配向した結晶性高分子のフィラメントを分子鎖方向にそ って压縮するとき，または屈曲変形を与えたとき内側の圧縮変形 部分に変形帯ができる。あるいは延伸膜を再延伸するとき分子鎖 が局所的に鋭く折れまがり変形帯あるいはキンク帯ができる。分 子鎖方向はキンク面に対しほぼ対称的に向きを変え, 試料の結晶 化度が高い程キンクは鋭くなる。

このような変形帯はせん断応力によって形成されるもので, Bosley'2)はこれを金属材料に打ける “Lüders band”に相当する ものと解した。

変形帯は分子鎖方向にそう滑り, あるいは高分子鎖自体がせん 断応力によってキンクを起しや寸い性格を持つことから生じたも のと考点られている。变形带には 2 種類あり, スリップ的なもの とキンク的なるのにわけられる。すなわち延伸組織の分子鎖方向 と平行に近いせん断力の作用で発生する, 分子鎖方向に対し 45 度あるいはそれ以下の傾むきをもつ変形带と, 分子銷方向に対し 直角に近い角度で形成される変形帯である。

変形帯形成は結晶性高分子の屈曲疲学破壞の先駆的現象である とする観察結果も報告されて㧍り, 実用的見地からも変形带形成 は重要であると思われる。

Frank ら³ 配向したポリエチレンフィラメントにさらにロー ルを加え，分子鎖方向と直角に压縮したとき，滑り扎よび双晶変 形によって面配向が起こることを報告している。

著者らはすでにポリエチレン延伸膜，6-ナイロン延伸膜を試料

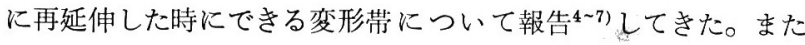
6,10-ナイロンフィラメントを分子鎖方向と直角に圧縮したとき，

*1 Masataka KURoKaWA, Takashi Konishi, Fumio TAKI, Ryosuke KAMEI 京都工芸緉維大学繊維学部：京都市左 京区松ヶ崎.

1) D. A.Zaukelis, J. Appl.Phys., 33, 569 (1962).

2) D. E. Bosley, Textile Res.J., 38, 141 (1968).

3) F.C.Frank, A. Keller, A. O'conner, Phil. Mag., 3, 64 (1958).

4）黒川, 小西, 阪野, 繊学誌, 22, 263 (1966).

5）黑川, 小西, 阪野, 近藤, 緘学誌, 23, 95 (1967).

6) 黒川, 小西, 阪野, 近藤, 綫学誌, 23,247 (1967).

7）黒川, 小西, 阪野, 近藤, 緎学誌, 24, 101 (1968).
通常のキンク带とは異なる変形が起ることを観察した ${ }^{8)}$ このよ らな変形の性質を偏光顕微鏡, 電子顕微鏡などで研究した結果を 報告する。

\section{2 実験}

市販の 6,10-ナイロンフィラメントで直径 0.5 0.8 mm のも の，6-ナイロン延伸フィラメントで直径 $0.5 \mathrm{~mm}$ のものを試料と した。延伸フィラメントにロールをかけ 2 重配向させた。一部試 料は結晶化度を妨るため, ロールをかけたのち適当な温度で熱 処理した。6,10-ナイロン延伸組織は $200^{\circ} \mathrm{C}$ 以上の高温で熱処理 すると内部構造の変化が起こることが X線干渉像の変化から確認 される。したがって熱処理温度は $180^{\circ} \mathrm{C} \sim 190^{\circ} \mathrm{C}$ までとどめた。

このような 2 重配向試料をさらに種々の温度で, ロ一ル面に垂 㨁およびロール面に平行に再度压縮したとき, 横断面拉よび生縮 面におこる局所的変形を直接光学顕微鏡で，またコロジオンカー ボンレプリカ法により電子顕微鏡で観察した。結晶配向のようす を知るためにはX線回折像を撮影した。

\section{3 結果および考察}

図 1 は 6,10-ナイ ン延伸フィライントを植徍の約 $25 \%$ およ び50\%圧延した試料のX線回折写真である。25\% 圧延では （100）面は压延面に活添垂直に配向し，50\% 生延では水素結合 面（010）面が压延面にほぼ平行に配向する。このような配向試料 を压延面に西直にさらに圧縮しても配向の性質は变らない。しか

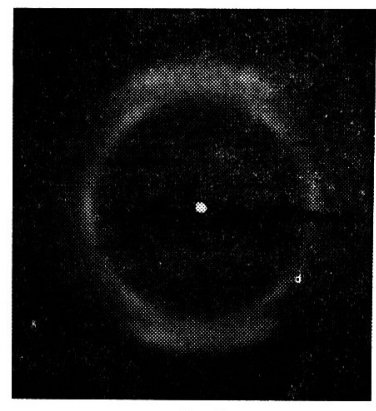

( a )

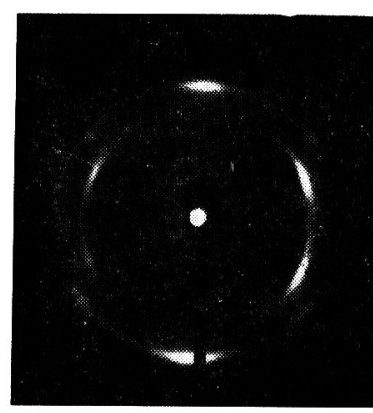

(b)
図 1 二重配向 6,10-ナイロン延伸フィラメントを直径 の約 25\%（a）拈よび 50\%（b）圧延した試料の $\mathrm{X}$ 線回折写真

熟処理温度: $190^{\circ} \mathrm{C}$ X線入射分问 : end 面

8) M.Kurokawa, et.al., Polymer Letter, 7, 319 (1969). 


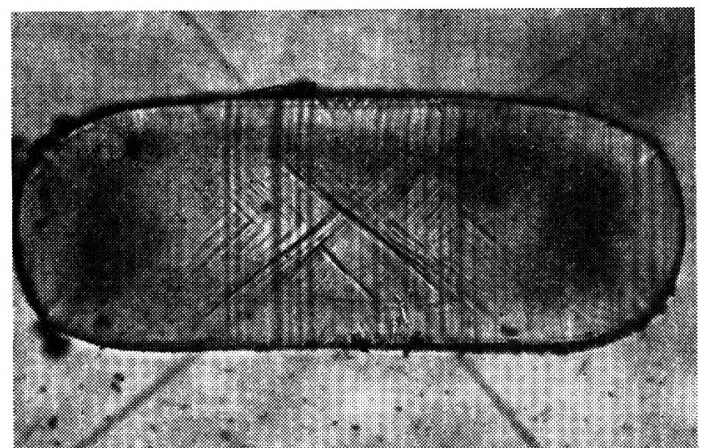

図 2 压縮方向の側面からみた光学顕微鏡写真 空缊，ロール面化垂直に $14 \%$ 圧縮

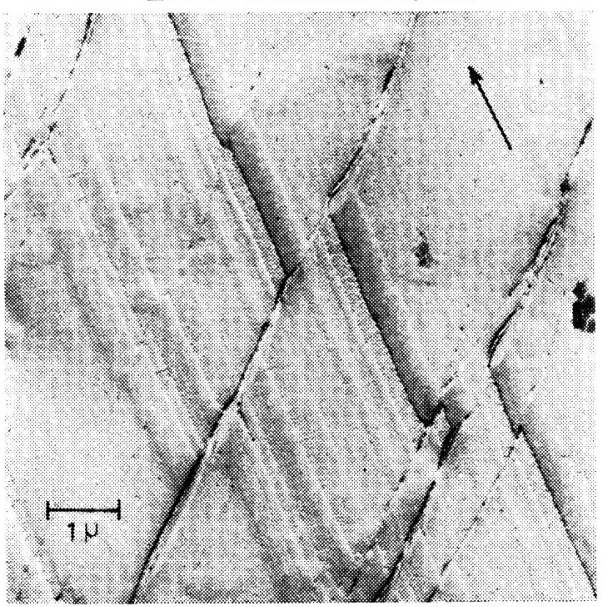

図 3 図 2 の試料の横断面の電子頙微鏡写真 矢印は切断方向

乙（010）干渉像は次第に涪や忖，水素結合面間の規則性が次第に 乱叔てくことがわかる。二重配向試料を压延面 (010) 面に垂直 に压縮したとき，横断面に生じる局部的な塑性变形を観察するた め，王延した試料をレザーで横断したのや，熱処理し，約 $10 \%$ 程度圧縮後, この横断面をコロジオンでレプリカし光学顕微鏡お。 よび電子顕微鏡で観察した。図 2 亿光学顕微鏡写真を, 図 3 亿電 子顕微鏡写真を示す。

横断面には压縮方向に対し 45 度近く傾むく斜交した歪み模様 および場合により圧縮方向に平行な丕㕛模様が認められる。この ような試料を任意の場所で横断したときの断面にも同様な斜交し た歪み模様が観察できる。二重配向試料ではすでに分子鎖は充分 に伸びているため，圧縮のさい分子鎖と平行な方向へは伸びず， 横方向へ拡がるだけで，平面歪みの条件に山たるものと思觉る。 そのため滑り線模様に相当する局所的变形が起っていると考兄る。

図 3 の電子顕微鏡写真で圧縮面に垂 直についたレザー・マークが斜め方向 そ移動しているのが認められる。移動 の量はいろいろで，このよらな移動が 試料中で終っている処も認められる。 すなわち一つの変形の線に沿ってでも 移動の量は場所により变っている。

変形部の深さは橫力向への移動量程 度のもので女ろう。圧縮試料の水素結 合面は压縮面に平行であるから，この ような移動が水素結合面を滑り面とす る滑り変形でないことは明らかであ

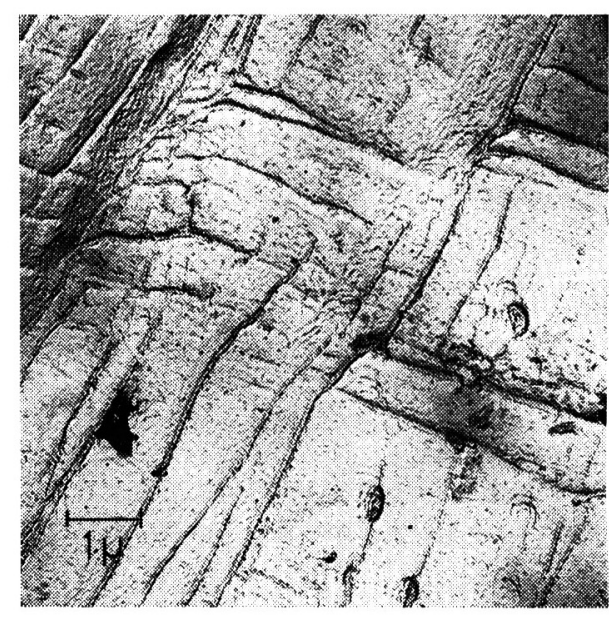

困 4 図 2 の試料の横断面をイオンェッチングした 電子顕微鏡写真

る。せん断応力最大の方向にそい，分子鎖と直角の方向に局所的 な滑り類似の塑性変形が起っている。この変形は金属材料などの ような結晶的な滑りではなく、移動が起っている変形部分では， 単結晶のクラック部分を橋渡しする延伸組織，女るいは非晶性高 分子のクレーズ部で热められる延伸組織などと同様に，局所的な 分子鎖方向の変化が起り，移動力向八分子鎖が配向していると考 えられる。

図 4 はイオン・エッチングした圧縮横断面のレプリカ像で女 る。変形部は移動方向に直角な周期構造を示している。このよう な周期構造は延伸組織をイオン・エッチングしたとき観察される エッチング像に相当するもので, 変形部で移動方向にそう分子鎖 の配向が起っていることを示している。端の面だけでなく任意の 場所で切断した横断面をイオン・エッチングしても弱くはあるが 同様のエッチング像が観察できる。したがって内部においても同 様な局所的な变形が起っている。すなわら普通の変形帯の場合と 同様に，未変形の部分の間に分子鎖の配向が変った変形部がはさ まれている。この変形部は非常に薄い上うに思われる。

2 重配向したフィラメントを环延面に平行で分子鎖方向に垂直 に圧縮したときのX線図形の变化を図 5 に示す。圧縮が強くなる に従って始め压延面に平行であった水素結合面 (010) 面は次第に 回転し，最後には再圧縮の方向と垂直な配向に移る。すなおち結 晶が $c$ 軸のまわりで 90 度回転するような結果を与兄る。図 6 は この変形のさいに横断面に現われた変形模様である。圧縮により 压縮方向と垂直なキンク面を持つキンクが起っている。圧縮が進

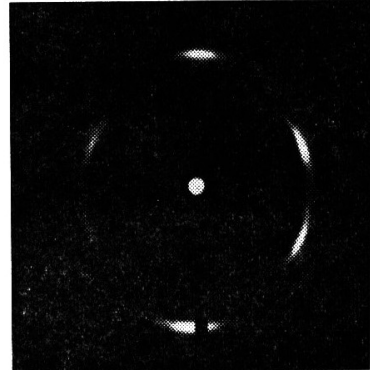

( a )

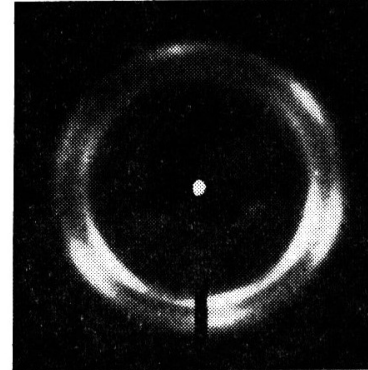

(b)

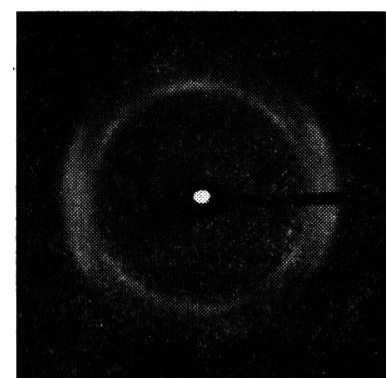

(c)
図 $550 \%$ 压延後 $190^{\circ} \mathrm{C}$ で熱処理した 2 重配向 6,10-ナイロンフィラメントの X線回折写真

（a）：2重配向 6,10-ナイロンフィラメント，(b)：40\%，(c)：60\%にロール面化平行に圧縮（室温） 


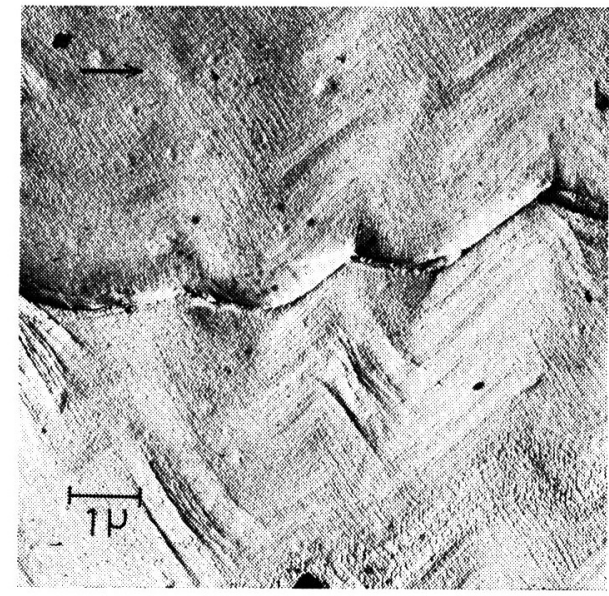

图 6 口ール面に平行に約15\%区縮した試料の横断面 飞現われる变形模樣の電子顕微鏡写真 矢印は切断方向

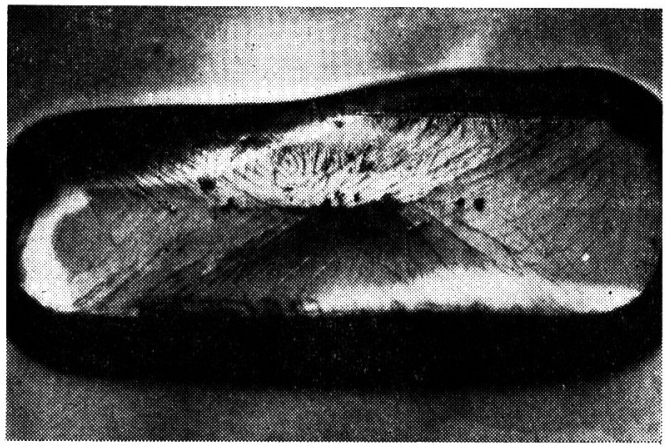

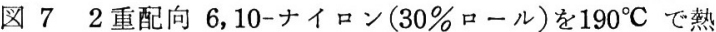
処理し， ロール面に垂直に $18^{\circ} \mathrm{C}$ で熱圧縮したときの 光学顕微鏡写真(end 面上り撮影)

むとともに，滑りと回転によりキンク角が次第に小さくなり，結 晶の向きが変ってゆくものと思われる。キンク帯は分子鎖方向だ けに生ずるものでなく, 分子鎖に対して直角な〈100〉方向にもキ ンク帯が生じ変形してゆくことがある。

2 重配向試料の圧縮変形のようすは圧縮温度によって影響を受 ける。30\% 圧延し， $190^{\circ} \mathrm{C}$ で熱处理した 2 重配向 6,10-ナイロン ・フィラメントを $180^{\circ} \mathrm{C}$ で压延面に垂直に压縮した試料の断面の 光学顕微鏡および電子顕凯鏡写真を図 7,8 亿示す。圧縮方向と 平行およびこれと斜交する昰及模様は室温の場合より著るしくな る。同時に分子鎖方向への凹凸が認められる。電子顕微鏡像でも 明瞭なステップが認められる。分子鎖方向への移動は斜交した変 形部扣よび王縮方向に平行な線にそって起っている。

加熱により延伸フィラメントはもしろ収縮を示す。たがって 熱圧縮の場合むしろ繊維軸方向への収縮と横方向への伸びが考え られる。収縮のさいに斜交バンド等の，いわば変形を起しやすい 線にそって局所的な収縮が起り，分子鎖方向への移動が起ったも のと考えられる。図 8 のステップの側面は特别なフィブリル状の 構造は認められない。しかし熱生縮前の試料の熱処理温度が低い 場合には図 9 のようにステップの側面にフィブリル状の延伸構造 が現われることが多い。

図 8のAの黒い粒状物の列は䟝離レプリカとして付着したもの で, 変化初期のミクロな変形の存在を間接に示している。Bはそ のような部分の側面と思われる。同様な粒状物の列はナイロン延 伸膜を再延伸するとき一般に誋められ, 微小変形の起っているこ

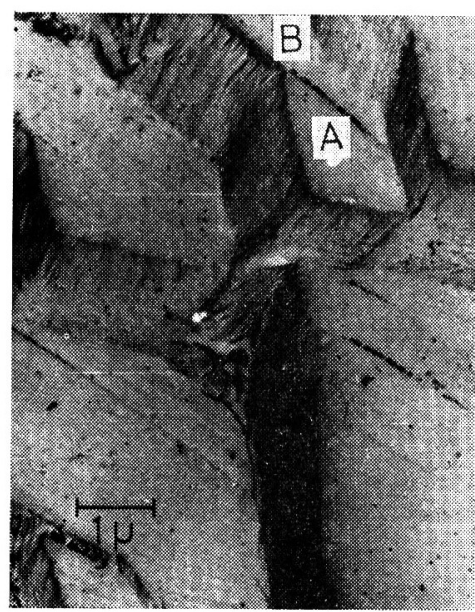

図 8 図 7 の試料の電子显微鏡写真

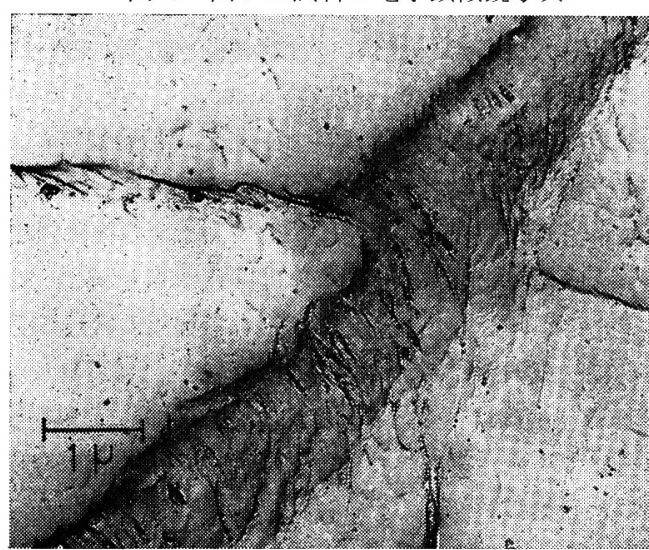

因 9 二重配向 6,10-ナイロンフィラメントを $170^{\circ} \mathrm{C}$ でロール面に垂直に熱圧縮したときの 電子顕微鏡写真 (end 面上り撮影)

とを示す。図8の場合凹の角にはこのような粒状物が認められな い。この角にミクロなクラックあるいはボイドのようなものがな いことを示している。このようなことから，局所的な収縮によっ て生じた分子鎖方向の移動は容 易で，抢そらく単純な滑りによ る移動ではなく，移動面にそっ て薄い変形部が生じそのとなり 合った部分を連結しているのが 普通でないかと考觉る。

図10のように延伸膜の端に 切りさきを加え，分子鎖方向と 平行にせん断力を加光ると, 図 のように変形带を形成し分子鎖 方向への移動が起る。さらにせ ん断力を加兄つづけると, 変形 帯の成長と同時にキンク面と一 定角度をなす方向に破断が進行 する。破断面の先端の歪みに， キンクのさいに起る歪みが加わ り破断が進行すると考えらい る。熱圧縮変形により横断面に 現われる分子鎖方向のステップ も機構的には類似のものでない

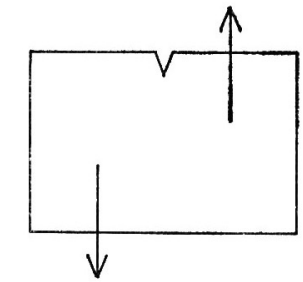

(a)

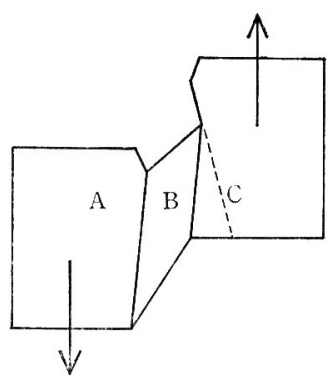

図10 配问した 6ーナイロン フィルムのせん断汒よる変形 (a)：米变形状態，(b)：変形状態 $\mathrm{A}:$ 来変形带部分, B : 资形部分, C : 破制の响 


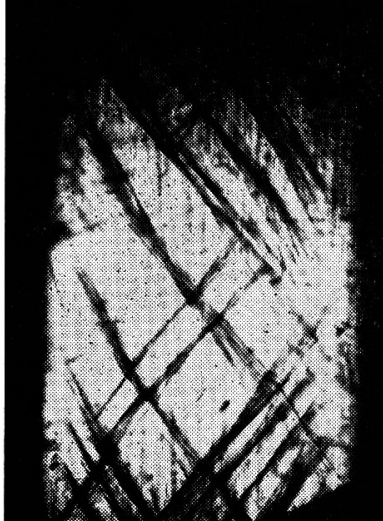

(a)

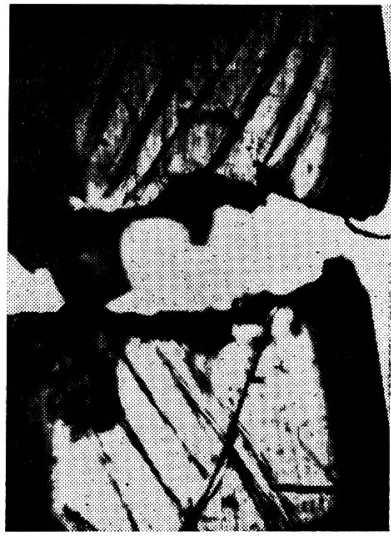

(b)

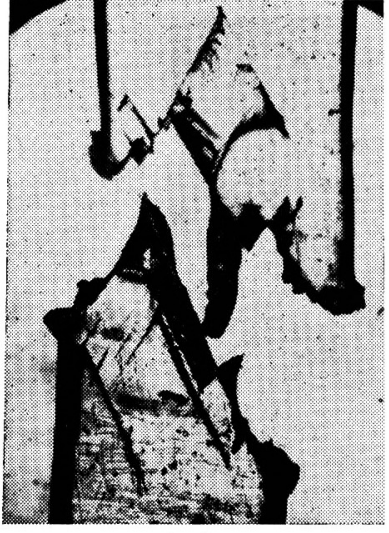

(c)
困 112 重配向 6,10-ナイロンフ イラメントを $180^{\circ} \mathrm{C} て ゙$ 熱圧縮した試料の光学顕微鏡写真 (a)：変形带，(b)：引張りに上る破断部分，（c）：変形带治沿った破断

熱圧縮のとき分子鎖方向への収縮 を和さえる，まるいはむしろ伸張応 力を加えると図 13 のようにこれら 斜交した変形带がクラックに成長す る。このことからもこれら斜交した 変形带が分子鎖のキンク，したがっ て全体の収縮と関係を持つものであ ることが推定される。

図 14 は熱圧縮試料を压縮面に平 行に機械的に引きさき，その面をレ プリカしたもので, 変形带部でキン クが起っていることが明らかであ る。図 15 はクラックに成長した変 形帯部分にそって切断し，クラック の表面が現われた処をレプリカした かと思われ，ステップの側面には变形带部の側面むるいは破断面 が現われているのであろう。

$150^{\circ} \mathrm{C}$ 程度以上での熱圧縮試料の圧縮面にも図 11 (a)のよう な斜交した変形帯が観察される。これらは試料表面にはほとんど 現われて扣らず，試料の内部で成長して扣りその幅は狭く，深さ もそれ程大きくない。横断面の光学顕微鏡写真を図 12 に示す。

熱王縮のさい, 分子鎖方向に熱収縮し, 横方向に拡がる。このよ らな条件は 6-ナイロン延伸膜を一次延伸方向と直角に高温で再 延伸する場合と類似している。再延伸膜の場合も分子鎖方向への 压縮と分子鎖と直角方向への伸びが起り，再延伸方向と 40 45 度傾さいた変形带ができる。

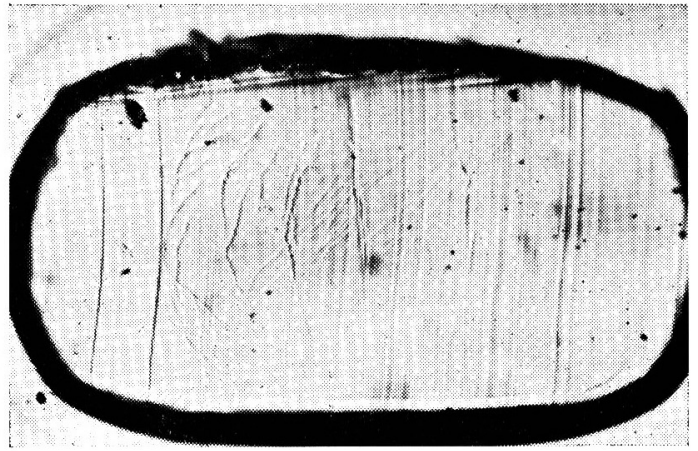

内12 因 11 (a) 試料の横断面の光学顕微鏡写真

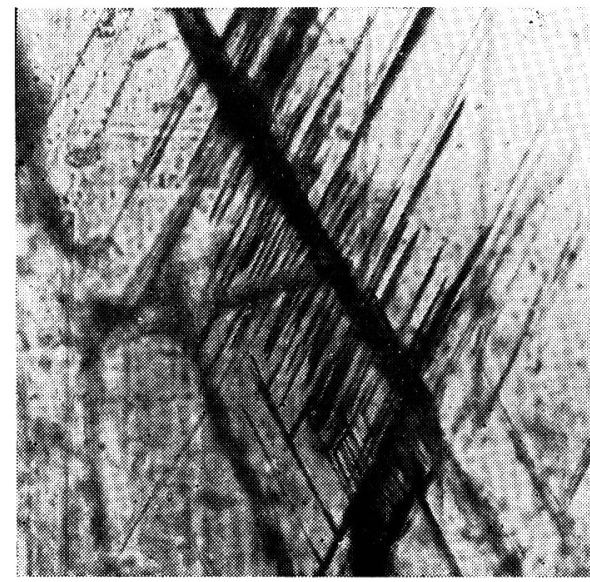

困 13 熱圧縮した 6,10-ナイロンフィラメントの変形 帯からクラックに成長した部分の光学顕徽鏡写真
写真でクラック表面はフィブリル状の延伸組織になって拉り, 分 子鎖の向きが変っている。図 16 は機断面のレプリカ像で, 切断 のとき受忛た力により，変形帯にそって破断が起りやすいことが わかる。破断面の一方にはフィプリル状の組織が見えるが，他の 面にはそのような構造は認められない。キンク面にそって破断が

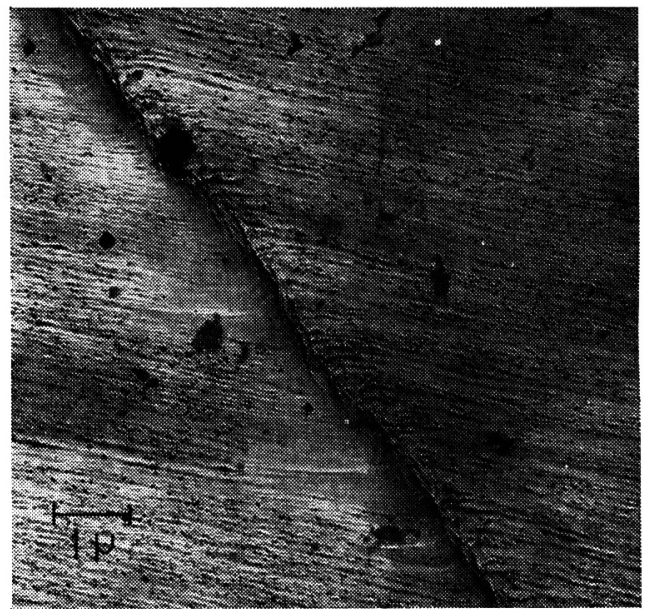

因 14 熱圧縮した 2 重配向 6,10-ナイロンフィラメント を機械的に引きさいた面の電子顕微鏡写真

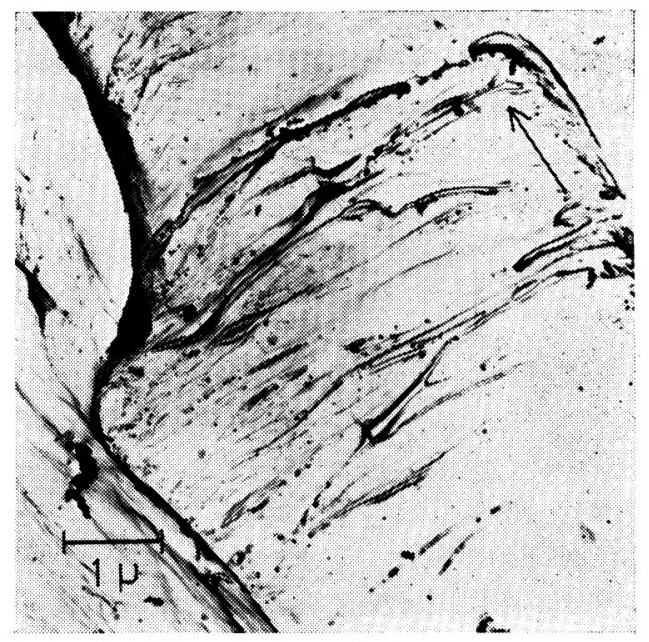

図 15 熱圧縮した 2 重配向 6,10-ナイロンフィラメン 卜横断面の電子顕微鏡写真

矢印性切断方向 


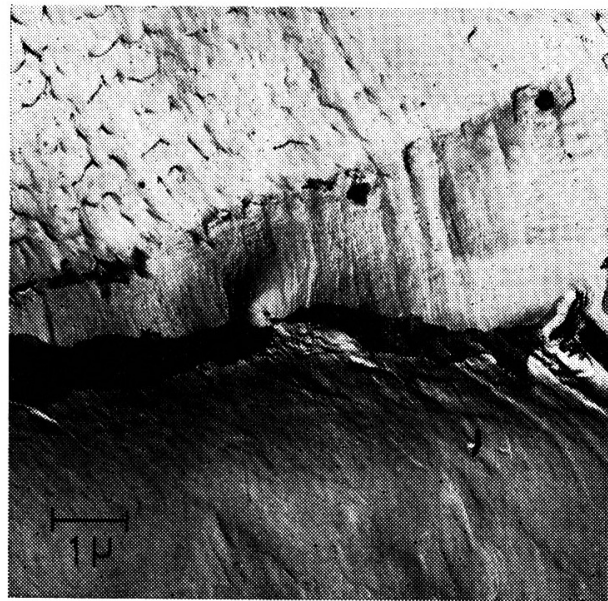

図 16 熱圧縮して変形帯の生じた 2 重配向 6,10-ナィ ロンフィラメント電子顕微鏡写真

压縮面に平行にレザーで薄く切ってある面のレプリカ像，矢印は切断方向

起りやすいようである。図 17 はクラックに成長した変形帯が試 料表面に現われたものでさけ目はフィブリル様のもので連絡して いるようにみえる。

斜交した変形带のできた試料をさらに延伸すると，明らかにこ れらの変形带にそって破断が起る場合と, そらでない場合がある （図 $11 （ b)$ ，（c））。クラックに成長している場合は確実に変形 帯にそって破断が起る。他方変形带のできた両延伸膜から試料片 を切りとり，始めの延伸方向に再度延伸寸ると切断は変形帯にそ

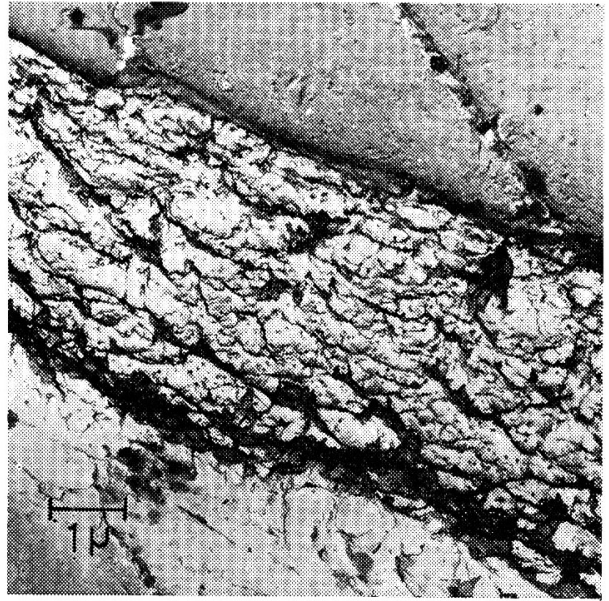

図 17 熱圧縮 してクラックの生じた 2 重配向 6,10-ナ イロンフィラメントの電子顕徽鏡写真

っては起らない。これらの結果から考えると, 普通の变形帯の場 合には強度にあまり影響がないが，これら変形带が成長しクラッ クに近くなっている場合は,この部分が弱点になり,これにそって 破断が起りやすくなる。キンク面での残留歪みが強度の低下を起 すのか, あるいは変形帯部にできた延伸配向組織の処では分子鎖 方向と直角に応力を受けることにより破断しやすいのであろう。 变形帯の成長に関係してどのような構造変化が起っているのかは 明らかでない。これらの点に関しては今後さらに研究を進めた w。

\title{
トランスーおよびシスー1, 4-ポリブタジエンの塩素化物の構造と物性
}

（昭 和 45 年 1 月 31 日 受 理）

\author{
竹田 政民・飯村一賀・遠藤 隆一*1
}

\begin{abstract}
赤外の測定から，塩素化トランス-拉よびシス-1,4-ポリブタジェンの局所的形態構造について研究した。塩素化重合体の局所的 形態構造は，2３-ジクロルブタンと 2,5-ジクロルヘキサンの回転異性体に関する知見から議論した。前者は掹素化重合体の塩素 化部分の，また後者はェチレン部分の構造単位のモデル化合物に対応する。固体状態ではいずれの塩素化重合体についてもその塩 素化部分では伸びたトランス形態の存在比がある程度多い。エチレン部分に関しては, Cl-trans-PB の炭素鎖はほとんどトランス 形態をとっているにもかかわらず，Cl-cis-PB ではゴーシュ形態がかなり多い。塩素化部分の形態構造の変化に対する溶媒効果は 2 つの塩素化重合体て異っている。この場合の形態構造の变化と溶液中での理想状熊のひろがりに関するパラメーターのとの間に 相関性があることが見出された。
\end{abstract}

\section{1 緒言}

トランスーおよびシス-1, 4-ポリブタジェンの 2 重結合に塩素を 付加して，それぞれの塩素化重合体 (Cl-trans-PB および Cl-cis$\mathrm{PB}$ と略称する) を得た。2 重結合への塩素化がトランス付加が 優勢であればこれらの塩素化重合体の塩素化部分の化学構造は, Cl-trans-PB ではメり゙型に，また $\mathrm{Cl}$-cis-PB ではラセミ型をと る。すなわら, 化学組成が同一で女りながら化学構造の異る高分 子化合物が得られることになる。この塩素化重合体の化学構造上

*1 Masatami TAKedA, Kazuyoshi IImURA, Ryūichi ENdō 東京理科大学理学部：東京都新宿区神楽坂.
の相異がその溶液物性や形態構造にぞのように反映されるかとい う問題は, ビニル重合体の立体規則性とその形態構造あるいは物 性との関係と同様に興味ある研究対象である。

本研究では, これらの塩素化重合体の赤外線吸収スペクトルを 測定することによって, 主としてその局所的形態構造を塩素化部 分とェチレン部分の二つにわけて検討し，すでにその一部を報告 した溶液物性1)のその後の研究結果と関連させて考察した*2。

塩素化部分の局所的形態構造については，その低分子モデル化

1) M. Takeda, R. Endō, Y. Matsuura, J.Polym. Sci., Part C, No. 23, 487 (1968).

*2 溶液物性の詳細に関しては別に発表の予定である。 